\title{
Immunohistochemical Examination of the Relationship Between Two Types of Mucous Neck Cell and the Intermediate Cells in the Rat Fundic Gland
}

\author{
By
}

\author{
Keiko FUJITA and Katsuji KANEKO
}

First Department of Anatomy, Saitama Medical School, 38 Morohongo, Moroyama, Iruma-gun, Saitama 350-04, Japan

- Received for Publication, May 25, $1994-$

Key Words: Gastric gland, Mucous neck cells, Intermediate cells, Hematoxylin, Immunoelectron microscopy

\begin{abstract}
Summary: It is generally accepted that the mucous neck cells are the precursors of chief cells, and that they are converted to chief cells via intermediate cells. We reported previously that two types of mucous neck cell are present in the region close to the cardia of the rat fundic gland. Using immunoelectron microscopy and lectin histochemistry, we examined whether the two histochemically distinct types of mucous neck cell are converted to chief cells via intermediate cells by the same process. Intermediate cells were positive for immunostaining with an antibody raised against neutral mucin but negative for staining with Limax flavus agglutinin (LFA). It is proposed that the mucous neck cells that contain neutral mucin are converted to chief cells via intermediate cells. The cells containing acidic mucin are first converted to mucous neck cells that contain neutral mucin and then to chief cells via intermediate cells.
\end{abstract}

It has been reported that the mucous neck cells are the precursors of chief cells, and that they are converted to chief cells via intermediate cells, which have characteristics of both mucous neck cells and chief cells (Townsend, 1961; Hunt and Hunt, 1962; Helander, 1969; Hattori and Fujita, 1976; Tamura and Fujita, 1983; Suzuki et al. 1983; Cornaggia et al. 1986; Ihida et al. 1988; Kantani and Kataoka, 1989; Madrid et al. 1990) In general, mucous neck cells are considered histochemically to be cells that stain positively for the PAS reaction, the GSA II reaction and upon paradox staining by Con A (Sheahan and Jervis, 1976; Wattel and Geuze, 1977; Katsuyama and Spicer, 1978; Ihida et al. 1988). We reported that two types of mucous neck cell [containing alcian blue ( $\mathrm{pH} \mathrm{2.5)} \mathrm{positive} \mathrm{acidic} \mathrm{mucin} \mathrm{or} \mathrm{containing}$ hematoxylin (pH 6) positive neutral mucin (Akita et al. 1985)] can be observed in the region close to the cardia (Kaneko et al. 1987).

It has been reported that the mucous neck cells are converted to chief cells via intermediate cells. However it is unknown whether both types of mucous neck cell are converted to chief cells via intermediate cells by the same process. We examined immunohistochemically the two types of mucous neck cell and the intermediate cells using an antibody against neutral mucin, which is stained by hematoxylin (pH 6). A lectin reaction with LFA, which is specific for sialic acid in the acidic mucin, was also performed in an attempt to reveal the relationships between the various types of cell.

The results suggest that mucous neck cells that contain acidic mucin are not converted directly to intermediate cells, but these cells are first converted to mucous neck cells that contain neutral mucin and then they are converted to chief cells via intermediate cells.

\section{Materials and Methods}

Isolation of hematoxylin-positive mucin from the gastric mucosa of the rat

The stomachs were removed from adult rats (Wistar; body weight, $300-400 \mathrm{~g}$ ). Incised specimens were rinsed with $0.001 \mathrm{M}$ EDTA $(\mathrm{pH} 7.4)$, and the mucosa of the corpus was scraped off by the procedure of Spee-Brand et al. (1980). The scraped mucosa was homogenized in $0.001 \mathrm{M}$ EDTA, and 2-mercaptoethanol was added to the homogenate to a final concentration of $0.5 \mathrm{M}$. The homogenate was mixed well and allowed to stand for $30 \mathrm{~min}$ at $37^{\circ} \mathrm{C}$. After centrifugation at $1,700 \mathrm{~g}$ for $20 \mathrm{~min}$, the supernatant was collected.

A column of Sephacryl S-1000 was pre-equilibrated with buffer $\mathrm{A}(0.5 \mathrm{M} \mathrm{NaCl}, 0.05 \mathrm{M}$ Tris- $\mathrm{HCl}, 0.001 \mathrm{M}$ 
EDTA pH 7.6) and $6 \mathrm{ml}$ of supernatant were loaded onto the column. The column was eluted with buffer $A$ at a flow rate of $34 \mathrm{ml} / \mathrm{h}$ and 100 fractions of $7.5 \mathrm{ml}$ each were collected. An aliquot of each fraction was blotted on a nitrocellulose membrane. The blotted membrane was stained with hematoxylin $(\mathrm{pH} \mathrm{6})$ or alcian blue ( $\mathrm{pH} 2.5)$ and subjected to the PAS reaction.

Fractions positive for hematoxylin and the PAS reaction but negative for alcian blue were collected and used as the antigen. Protein was quantitated by the procedure of Lowry (Lowry et al. 1951) with BSA as the standard.

\section{Immunization}

Hematoxylin-positive fractions $(0.7 \mathrm{ml})$ were mixed with an equal volume of Freund's complete adjuvant, and a uniform suspension was injected subcutaneously into the digital pad of a rabbit's paw. Two weeks later, $0.7 \mathrm{ml}$ of the hematoxylin-positive fraction plus the same volume of Freund's incomplete adjuvant was injected into the dorsum of each previously treated rabbit. The animals were then immunized in the same manner every week for 4 weeks. Upon completion of the fourth immunization, whole blood was collected and the separated serum was stored at $-20^{\circ} \mathrm{C}$ until use.

Determination of specificity of the reaction of the prepared antiserum with the epithelium of the gastric mucosa of the rat

Hematoxylin-positive mucin was used as the antigen for determining the specificity of the antiserum obtained from the immunized rabbits.

The mucosa of the gastric corpus from adult rats was fixed with half-strength Karnovsky's fixative, embedded in Lowicryl $\mathrm{K} 4 \mathrm{M}$, and $3 \mu \mathrm{m}$ sections were prepared. The sections were reacted with $0.3 \%$ hydrogen peroxide for $20 \mathrm{~min}$, treated with a $5 \%$ solution of BSA in phosphate-buffered saline (PBS) for $10 \mathrm{~min}$ and rinsed with PBS. Then the sections were reacted with antiserum that had been diluted 100 to 2,000 fold with PBS for $30 \mathrm{~min}$. The sections were rinsed in PBS and reacted with horseradish peroxidase labeled antibodies raised in goat against rabbit IgG (E-Y Laboratories, San Mateo, CA) for $30 \mathrm{~min}$. Bound antibodies were visualized with a Histofine AEC Kit for peroxidase (Seikagaku Kogyo, Tokyo).

Confirmation of the specificity of the antiserum by an immunoblotting test

The antigen (hematoxylin-positive mucin) was blotted on a nitrocellulose membrane. After drying, the blotted membrane was immunologically stained with the antiserum. The same procedure as used for staining of sections of the rat gastric mucosa was applied to immunostaining of the membrane.

Preparation of ultrathin sections and immunoelectron microscopy

Mucosa of the gastric corpus of 3-week-old and adult rats was fixed with half-strength Karnovsky's fixative, dehydrated in ethanol, embedded in Epon 812 and cut into ultrathin sections. After etching of the ultrathin sections for $5 \mathrm{~min}$ with $0.001 \%$ benzene, $5 \%$ methanol and $5 \%$ ethanol, sections were rinsed with water, immersed in PBS and then immersed in $1 \%$ BSA for $10 \mathrm{~min}$ and rinsed again with PBS. Sections were then treated with antiserum that had been diluted with PBS (1:100) for $30 \mathrm{~min}$ and rinsed with PBS. They were then treated with goat antibodies against rabbit IgG (E-Y Laboratories), conjugated with colloidal gold (particle diameter, $15 \mathrm{~nm}$ ) for $30 \mathrm{~min}$ and rinsed with PBS. Sections were rinsed with distilled water and counterstained with uranyl acetate for observation under an electron microscope (H-7000; Hitachi, Tokyo, Japan).

In the case of controls, immunostaining was performed with serum from a normal rabbit or by omission of the reaction with the primary antigen.

\section{Staining with lectin by the postembedding method}

Sections were etched as described above and rinsed with water. After immersion in PBS and 1\% BSA for $10 \mathrm{~min}$ the sections were rinsed again with PBS. They were then treated with LFA conjugated with colloidal gold (particle diameter, $5 \mathrm{~nm}, 15 \mathrm{~nm}$; E-Y Laboratories) for $30 \mathrm{~min}$ and rinsed with PBS. After rinsing with distilled water, the sections were counterstained with uranyl acetate and observed under an electron microscope.

\section{Digestion with neuraminidase}

Digestion with neuraminidase was performed to reveal the presence of sialic acid in acidic mucin. Sections were incubated with neuraminidase $(0.5 \mathrm{mg} /$ $\mathrm{ml})$ in $0.1 \mathrm{M}$ acetate buffer that contained $0.04 \mathrm{M}$ $\mathrm{CaCl}_{2}$ at $\mathrm{pH} 5.5$, for $18 \mathrm{~h}$ at $40^{\circ} \mathrm{C}$. After digestion, sections were stained with hematoxylin ( $\mathrm{pH} \mathrm{6)}$.

\section{Results}

\section{Reactivity of the antiserum}

Microscopic inspection confirmed that mucous neck cells reacted with the antiserum obtained from a rabbit that had been immunized with hematoxylin (pH 6) positive mucin as the antigen. This result agreed with results of our previous experiments. 


\section{Immunoelectron microscopy}

Fundic epithelium from the stomach of 3-weekold rats was immunologically stained by the postembedding method. In the intermediate cells, granules consisting of electron-opaque and electron-lucent zones were seen. Only the electron-lucent zones were labeled with colloidal gold particles (Fig. 1). In the fundic epithelium from adult rats, labeling with colloidal gold particles was observed in the mucous neck cells that contained electron-lucent zones and amorphous granules in the neck portion and in the lower portion toward the bottom of the fundic glands.

Closed to the bottom of the glands, mucous neck cells with nonamorphous granules, heterogeneous granules or granules with bipartite structure were observed. In such mucous neck cells, only the electron-lucent zones of granules were labeled with colloidal gold particles (Fig. 2).

\section{Lectin histochemistry}

In the fundic epithelium from the stomach of 3-week-old rats, intermediate cells were negative for staining with LFA.

In adult rats, the electron-lucent zones of granules in the mucous neck cells from the neck portion were positive for the LFA reaction.

In the lower part of the neck portion, towards the bottom, the mucous neck cells were not labeled by colloidal gold particles, Further toward the bottom, mucous neck cells were also not labeled by colloidal gold particles (Fig. 3).

\section{Neuraminidase digestion}

After digestion with neuraminidase, mucous neck cells containing alcian blue ( $\mathrm{pH} 2.5)$ positive acidic mucin in the upper neck region stained violet with hematoxylin ( $\mathrm{pH}$ 6).

\section{Discussion}

It has been reported that mucous neck cells are converted to chief cells via intermediate cells. We reported previously that mucous neck cells that contain acidic mucin are distributed in the upper region of glands above mucous neck cells that contain neutral mucin, and that two types of mucous neck cell can be observed (Kaneko et al. 1987). If both types of mucous neck cell, i.e., those containing acidic mucin and those containing neutral mucin, are converted to chief cells via intermediate cells, one would expect to find two types of intermediate cell and chief cell that corresponded to the different origins. Cornaggia et al. (1986) reported that pepsinogen (Pg) I and Pg II are excreted by chief cells and that $\mathrm{Pg} \mathrm{I}$ is limited to the fundic mucosa while $\mathrm{Pg}$
II is restricted to the fundic, antral, and proximal duodenal mucosa. These findings may have some relationship to the heterogeneity of mucous neck cells and intermediate cells. However, in this study we obtained no results to indicate that there might be two types of intermediate cell. Since the electronlucent zones of granules in the intermediate cells from the stomach of both the 3-week-old rat and the adult rat were immunostained with antibodies for hematoxylin-positive mucin, we confirmed that intermediate cells contain hematoxylin-positive mucin, as do the mucous neck cells. However, after treatment of sections with neuraminidase, mucous neck cells containing acidic mucin became stainable with hematoxylin (pH 6) (Kaneko et al. 1987). Therefore, it was apparent that mucous neck cells containing either acidic mucin or neutral mucin have the same components. Moreover, from the above results, the components of two types of mucous neck cell seem to be closely related to those of intermediate cells. When the differentiation of gastric glandular cells occurs from the neck region to the fundic region, mucous neck cells containing acidic mucin may be converted to cells that contain neutral mucin. Furthermore, the cells containing neutral mucin may be converted to chief cells via intermediate cells.

\section{References}

1) Akita M, Murata E, Fujita K. and Kaneko K. A new method using a modified Mayer's hemalum at $\mathrm{pH} 6$ for demonstrating mucous neck cells. Stain Tech 1985;60:261-264.

2) Cornaggia M, Capella C, Riva C, Finzi G. and Solcia E. Electron immunocytochemical localization of pepsinogen I (Pg I) in chief cells, mucous neck cells and transitional mucous neck/chief cells of the human fundic mucosa. Histochemistry 1986;85:5-11.

3) Hattori $T$. and Fujita $S$. Tritiated thymidine autoradiographic study on cellular migration in the gastric gland of the golden hamster. Cell Tiss Res 1976;172:171-184.

4) Helander HF. Ultrastructure and function of gastric mucoid and zymogen cells in the rat during development. Gastroenterology 1969;56:53-70.

5) Hunt TE. and Hunt EA. Radioautographic study of proliferation in the stomach of the rat using thymidine ${ }^{3} \mathrm{H}$ and compound 48/80. Anat Rec 1962;142:505-517.

6) Ihida K, Suganuma T, Tsuyama S. and Murata F. Glycoconjugate histochemistry of the rat fundic gland using Griffonia simplicifolia agglutinin-II during the development. Am J Anat 1988;182:250-256.

7) Kaneko K, Murata E, Fujita $K$. and Akita M. On the distribution of neutral and acidic mucous neck cells in the rat gastroduodenal mucosa with the method of hematoxylin (pH 6), high iron diamine and alcian blue stains. Folia Anat Jpn 1987;64:131-140.

8) Kantani A. and Kataoka K. A carbohydrate histochemical study on surface mucous cells, mucous neck cells and chief cells in the gastric mucosa of developing mice. Arch Histol Cytol 1989;52:37-50. 
Plate I

9) Katsuyama T. and Spicer SS. Histochemical differentiation of complex carbohydrates with variant of the Concanavalin A-horseradish peroxidase methods. J Histochem Cytochem 1978;26:233-250.

10) Lowry $\mathrm{OH}$, Rosebrough NJ, Farr AL. and Randall RJ. Protein measurement with the folin phenol reagent. J Biol Chem 1951;193:265-275.

11) Madrid JF, Ballesta J, Castells MT. and Hernandez F. Glycoconjugate distribution in the human fundic mucosa revealed by lectin- and glycoprotein-gold cytochemistry. Histochemistry 1990;95:179-187.

12) Sheahan DG. and Jervis HR. Comparative histochemistry of gastrointestinal mucosubstances. Am J Anat 1976;146: 103-132.

13) Spee-Brand R, Strous JAM. and Kramer MF. Isolation and partial characterization of rat gastric mucous glycoprotein Biochim Biophys Acta 1980;621:104-116.

14) Suzuki S, Tsuyama S. and Murata F. Cells intermediate between mucous neck cells and chief cells in rat stomach. Cell Tiss Res 1983;233:475-484.

15) Tamura S. and Fujita H. Fine structural aspects on the renewal and development of surface mucous neck cells and glandular cells of the gastric body of the adult golden hamster. Arch Histol Jpn 1983;46:501-521.

16) Townsend SF. Regeneration of gastric mucosa in rats. Am J Anat 1961;109:133-147.

17) Wattel W. and Geuze JJ. Ultrastructural and carbohydrate histochemical studies on the differentiation and renewal of mucous cells in the rat gastric fundus. Cell Tiss Res 1977; 176:445-462.

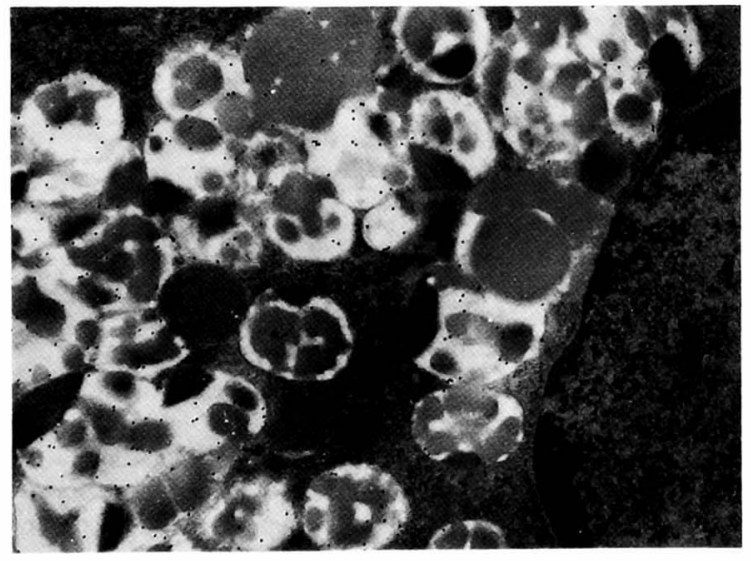

\section{Explanations of Figures}

\section{Plate I}

Fig. 1. Fundic epithelium from the stomach of a 3-week-old rat immunostained with antibody for hematoxylin (pH 6) positive mucin. In the intermediate cells, only the electron lucent-zones were labeled by colloidal gold particles. $\times 15,000$. 
Plate II
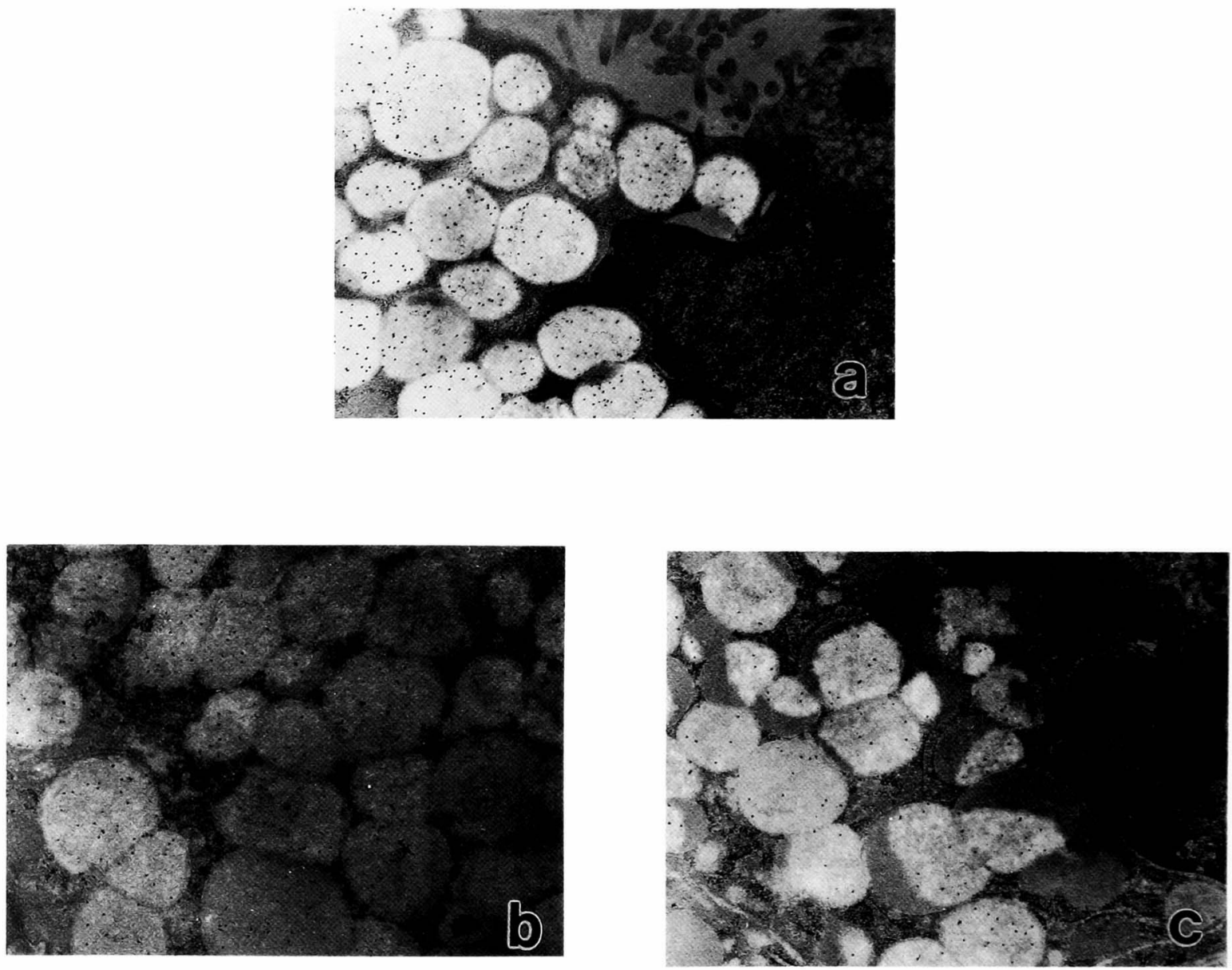

\section{Plate II}

Fig. 2. Immuno staining with antibody for hematoxylin ( $\mathrm{pH}$ 6) positive mucin. Fundic epithelium from the stomach of an adult rat. $\times 15,000$.

(a) In mucous neck cells, electron lucent zones and amorphous granules in the neck portion of the fundic gland were labeled by colloidal gold particles. (b) In the neck portion toward the bottom, mucous neck cells with nonamorphous granules were observed. (c) Further toward the bottom, mucous neck cells with heterogeneous granules and granules with bipartite structure were labeled. 
Plate III
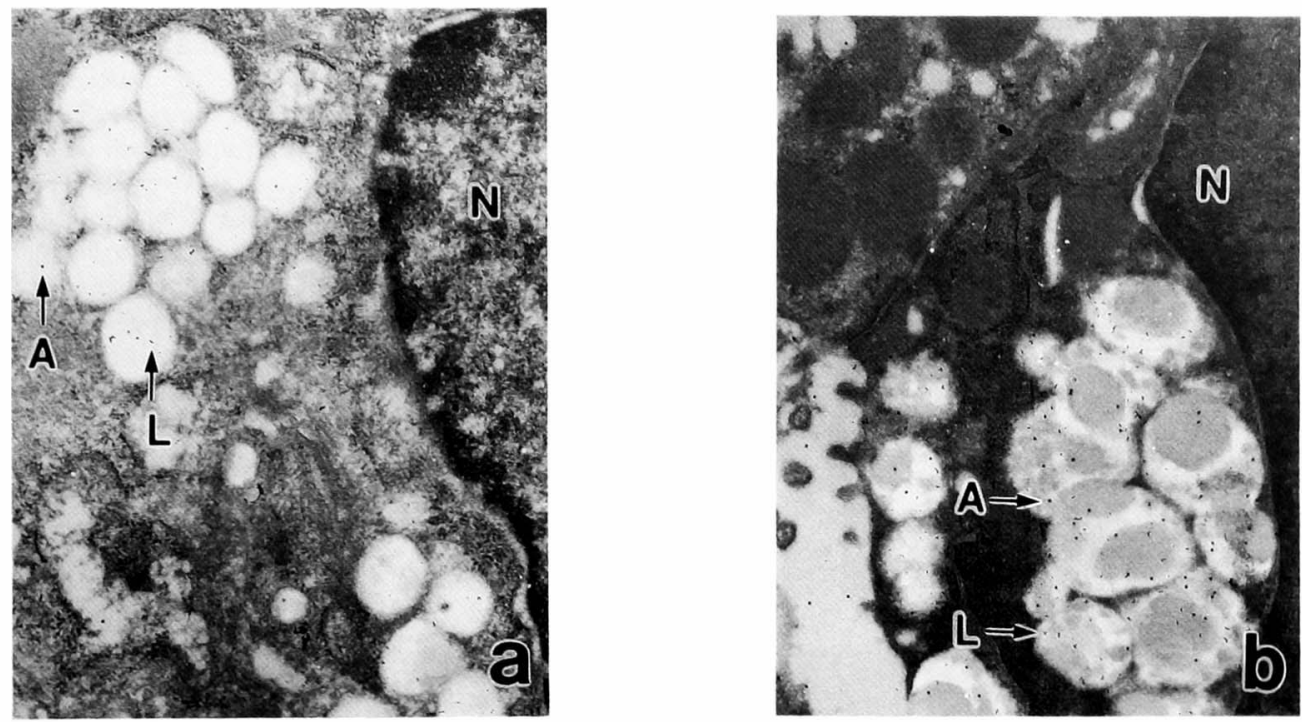

\section{Plate III}

Fig. 3. In an adult fundic gland, the granules of mucous neck cells were stained with antibody and with LFA. $\times 15,000$. A: antibody, L: LFA, N: nucleus.

(a) In the neck portion, the labeling intensity of LFA colloidal gold $(5 \mathrm{~nm})$ in the granules of mucous neck cells were stronger than that of antibody colloidal gold $(15 \mathrm{~nm})$. (b) In the neck portion toward the bottom, the granules of mucous neck cells were labeled with both antibody colloidal gold $(15 \mathrm{~nm})$ and LFA colloidal gold $(5 \mathrm{~nm})$. 